\title{
Growth of triploid oyster, Crassostrea madrasensis (Preston)
}

\author{
Jyothi V Mallia', Palaniyappan Muthiah ${ }^{2}$ \& Palahani C Thomas ${ }^{1}$ \\ ${ }^{1}$ Central Marine Fisheries Research Institute, Kochi, India \\ ${ }^{2}$ TRC of CMFRI, Tuticorin, Tamil Nadu, India
}

Correspondence: J V Mallia, Central Marine Fisheries Research Institute, PB No. 1603, Ernakulam North PO, Kochi, Kerala 682 018, India. E-mail: jyothivmallia@rediffmail.com

\begin{abstract}
The performance of I and II meiotic triploids and control oysters (Crassostrea madrasensis) reared at Tuticorin Bay was compared to determine if the improvements in the growth of edible oysters were additive to faster growth in triploids. After a grow-out period of 12 months, both mean whole weights and shell heights were in order I meiotic triploid > II meiotic triploid > control. Mean whole weights and shell height of different oyster lines were all significantly different $(P<0.05)$. On an average, larger morphological traits indicated that growth improvements from triploids were additive, and throughout the study triploid oysters maintained faster growth rate than their diploid siblings. Condition index and adductor muscle diameter of both triploids were higher than those of control.
\end{abstract}

Keywords: I and II meiotic triploids, 6-DMAP, condition index, adductor muscle diameter

\section{Introduction}

Crassostrea madrasensis (Preston) is an ideal species for culture because of a fast growth rate and tolerance to a wide range of salinity. They occur all along the Indian coasts in backwaters, bays and estuaries. The Central Marine Fisheries Research Institute (CMFRI), the premier research institution in India, has been giving a thrust on oyster culture for the past 25 years, which has resulted in the evolution of a complete package of oyster culture technology, including hatchery production of the seed. Through various programmes, the techniques for oyster culture have been extended to fishermen, leading to the establishment of 33 oyster farms along the Kerala coast, India. The international market value of $1 \mathrm{~kg}$ of chilled/frozen oyster meat (diploid) varies from Rs. 125 to 300/- (Appukuttan \& Muthiah 1996).

Triploid induction is usually considered as a method for enhancing production. The main benefits to be derived from triploidy include increase in growth rates and higher meat yields due to sterility. Since the initiation of triploidy induction in oysters by Stanley, Allen Jr and Hidu (1981), many studies have been conducted on the production of triploids, indicating their advantages in growth and marketing over the diploid siblings (Tabarini 1984; Allen \& Downing 1986; Mason, Shumway, Allen Jr \& Hidu 1988; Komaru \& Wada 1989). Beaumont and Kelly (1989) and Utting, Millican and Laing (1996) reported significantly greater shell height of triploid larvae. Matthiessen and Davis (1992) reported that triploid American oyster Crassostrea virginica survived at a higher percentage than diploid oysters exposed to the parasite Haplosporidium nelsoni. Gardner, Maguire and Kent (1996) indicated a larger adductor muscle index in triploid oysters compared with diploids. Substantial size differences of the adductor muscle between diploid and triploid Pacific oysters (Crassostrea gigas) have been reported (Akashige 1990). Nell, Cox, Smith and Maguire (1994), comparing the performances of triploid Saccostrea commercialis over diploid siblings, observed higher dry meat weight, higher condition index and faster growth in triploids. Reduction of grow-out time was another advantage of triploids (Graham 1991) by which about $20 \%$ of the labour cost would be reduced. Higher survival of triploid hatchery stocks with better meat condition during winter compared with wild diploids 
would further improve the profitability in oyster farms (Hand, Nell \& Maguire 1998). Enhanced performance of triploid bivalve is generally attributed to increased energy diversion to somatic growth because of limited gametogenesis (Tabarini 1984; Allen \& Downing 1986; Ruiz-verdugo, Ramrez, Allen Jr \& Ibarra 2000). In addition to oyster size, the meat condition, proportions of shell by weight and shell cavity size are all factors that influence the marketability of oysters.

This paper deals with a comparative study conducted between triploids of C. madrasensis and diploid controls. In this study, morphometric characters such as shell height, breadth, weight, condition index, dry meat weight and adductor muscle diameter (AMD) were evaluated for triploids of C. madrasensis.

\section{Materials and methods}

Mature animals of C. madrasensis were collected from both natural beds and the oyster farm of CMFRI at Tuticorin, Tamil Nadu. Samples of 10 oysters were opened for checking the gonad maturity stage and the mature ones were induced for spawning. Those in the maturing stage were kept in the conditioning room, where they were intensively fed with mixed algal culture at $22 \pm 1{ }^{\circ} \mathrm{C}$ (Nayar, Rao, Rajapandian \& Gopinathan 1987). But when this did not work, 'strip spawning' was used.

The fertilized eggs were incubated with $100 \mu \mathrm{M} 6$ dimethylaminopurine (6-DMAP) for $8 \mathrm{~min}$ to induce both I and II meiotic triploids. Triploid induction treatments were administered 8 min after fertilization for producing I meiotic triploids and 17 min after fertilization for II meiotic triploids. Untreated fertilized diploid eggs were separately reared as controls. For each treatment, triplicates were maintained and the larvae were reared in $40 \mathrm{~L}$ plastic trough at a larval density of 5 larvae $\mathrm{mL}^{-1}$. The whole filtered seawater was changed on alternate days. Isochrysis galbana was cultured following serial dilution techniques (Gopinathan 1982). The feeding rate and rearing density for the larvae at various stages was followed as in Table 1. The water temperature ranged from 29 to $31{ }^{\circ} \mathrm{C}$ and salinity from 31 to $33 \mathrm{mg} \mathrm{L}^{-1}$ and $\mathrm{pH}$ varied from 8.1 to 8.2. Gentle aeration was given to the larval rearing trough.

On the 3rd, 6th, 9th, 12 th and 15 th day of postfertilization, 20 larvae were fixed in $1 \%$ formalin and the anterior-posterior axis measurement (shell height) was taken. When the eyed stage was attained, the in-
Table 1 Rearing density and algal cell concentration

\begin{tabular}{|c|c|c|}
\hline Stage of larvae & $\begin{array}{l}\text { Density of } \\
\text { larvae } \mathrm{mL}^{-1}\end{array}$ & $\begin{array}{l}\text { Algal cell } \\
\text { concentration } \\
\text { in } \mathrm{mL} \text { larvae } \\
\text { day }^{-1}\end{array}$ \\
\hline Straight-hinge & 5 & $3000-4000$ \\
\hline Umbo & 3 & $4000-5000$ \\
\hline Advanced umbo to eyed & 2 & $5000-8000$ \\
\hline Pediveliger & 2 & $10000-12000$ \\
\hline
\end{tabular}

Source: Nayar, Rao, Rajapandian and Gopinathan (1987).

ner side and bottom of the rearing trough was fixed with polythene linear sheet for spat settlement. After settlement, the spats were reared for 3 weeks in their respective troughs by providing mixed algae consisting of Chaetoceros sp.,Thalassiosira sp. and Nitzchia sp at a ratio as presented in Table 1. After rearing for 3 weeks, spats were removed from the polythene sheet and were kept in seperate rearing cages of $40 \times 40 \times 10 \mathrm{~cm}$ webbed with synthetic twine and enriched with velon screen. The cages were suspended from a rack erected in an intertidal area in the Tuticorin Bay.

The young oysters were reared for a year in the same conditions. Every 3 months, 20 oysters were measured for length and breadth using Vernier calipers. Weight measurements to the nearest $0.01 \mathrm{~g}$ were made. The diameter of the adductor muscle was recorded and condition factor was estimated following the method of Crosby and Gale (1990) for a sample of 10 oysters in each treatment. The dry weight of the meat was determined after drying in an oven at $60{ }^{\circ} \mathrm{C}$ for $48 \mathrm{~h}$.

The mean values of the observations made for each treatment were statistically analysed for significant differences $(P<0.05)$ by ANOVA using SYSTAT 7.0.

\section{Results}

\section{Larval growth}

The average larval growth rate for diploid, II meiotic and I meiotic was 12.9, 15.8 and $17.5 \mu \mathrm{m}$, respectively (Table 2). On day 15, the length of the diploid larvae was only $194.2 \pm 5.3 \mu \mathrm{m}$ whereas II meiotic and I meiotic larvae attained $237.4 \pm 11.08$ and $262.3 \pm 10.5 \mu \mathrm{m}$ respectively. The differences in larval length between diploid and both types of (II and I) triploids were found to be significant $(P<0.05)$. 
Table 2 Comparison of shell length of triploid and diploid larvae of Crassostrea madrasensis

\begin{tabular}{|c|c|c|c|}
\hline \multirow[b]{3}{*}{ Days } & \multicolumn{3}{|c|}{ Shell height* $(\mu \mathrm{m})$} \\
\hline & \multicolumn{3}{|l|}{ Treatment } \\
\hline & I meiotic & II meiotic & Control \\
\hline 3 & $79.7 \pm 2.21$ & $58.1 \pm 4.48$ & $51.5 \pm 3.88$ \\
\hline 6 & $83 \pm 4.95$ & $64.7 \pm 2.98$ & $71.4 \pm 3.54$ \\
\hline 9 & $162.7 \pm 6.91$ & $132.8 \pm 4.29$ & $131.1 \pm 5.78$ \\
\hline 12 & $205.8 \pm 5.07$ & $159.4 \pm 3.67$ & $152.7 \pm 4.82$ \\
\hline 15 & $262.3 \pm 10.45$ & $237.4 \pm 11.08$ & $194.2 \pm 5.34$ \\
\hline
\end{tabular}

*All values are expressed as mean \pm SE $P<0.05$.

Table 3 Survival $(\%)^{*}$ of triploid and diploid larvae of Crassostrea madrasensis

\begin{tabular}{llll}
\hline $\begin{array}{l}\text { Group } \\
\text { Day }\end{array}$ & I meiosis & II meiosis & \multicolumn{1}{l}{ Control } \\
\hline 1st & $86.90 \pm 1.82$ & $85.71 \pm 1.38$ & $92.06 \pm 0.79$ \\
2nd & $50.70 \pm 0.68$ & $48.62 \pm 0.78$ & $56.46 \pm 0.33$ \\
4th & $34.72 \pm 0.54$ & $33.53 \pm 0.74$ & $50.99 \pm 0.16$ \\
6th & $17.71 \pm 0.22$ & $17.46 \pm 0.18$ & $32.89 \pm 0.32$ \\
20th (spat) & $4.55 \pm 0.68$ & $5.247 \pm 1.06$ & $6.69 \pm 0.45$ \\
\hline
\end{tabular}

${ }^{*}$ All values are expressed as mean \pm SE. $P<0.05$.

\section{Larval survival}

The survival of the diploid larvae on the first day was $92.06 \pm 0.8 \%$, which came down to $6.69 \pm 0.45 \%$ on day 20. Final survival of $5.25 \pm 1.06 \%$ was observed for II meiotic triploids. I meiotic larvae had less survival of $4.55 \pm 0.68 \%$ (Table 3). Regarding larval survivability, the diploid had higher $(6.7 \%)$ survival than the $5.2 \%$ and $4.5 \%$ seen in II meiotic and I meiotic larvae. The low survival of triploid larvae in this study may be attributed to the quality of eggs obtained through stripping.

\section{Juvenile growth}

Shell height

The progressive increase in the shell height of the oysters is given in Fig. 1. From the mean length of $7.1 \mathrm{~mm}$, the diploid oysters had grown to $18.7 \pm 1.76$, $34.6 \pm 2.83$ and $40.1 \pm 3.38 \mathrm{~mm}$ in the 3rd, 6 th and 9th months, respectively. The mean difference in shell height between I meiotic triploids and diploids was $87.3 \%$ and that between II meiotic triploid and diploids was 53.44 . The ANOVA indicated a significant relationship between the shell height of I meiotic triploids and control $(P<0.005)$ and II meiotic triploids and control $(P<0.005)$.

\section{Breadth}

In terms of breadth, the diploid oysters had grown from $5.8 \pm 0.3$ to $27.5 \pm 2.09$ and $36.3 \pm 3.31 \mathrm{~mm}$ in the sixth and 12th months (Fig. 2). Statistical analysis gives a significant difference between I meiotic and control and II meiotic and control.

\section{Weight}

In the diploid, the mean weight was $9.4 \pm 1.84 \mathrm{~g}$ in the 12th month. The weight increase was $0.78 \mathrm{~g} \mathrm{month}^{-1}$ (Fig. 3). A high level of significance in shell-on weight was also observed between I meiotic triploids and diploid $(P<0.005)$ with a $260 \%$ difference. The weight increase of II meiotic triploids and diploid was also significant $(P<0.005)$ and the difference in weight between them was $128 \%$.

\section{$A M D$}

The AMD of I meiotic triploid was 50.5\% and of II meiotic triploid was $22.3 \%$ more than that of the diploid (Table 5). The difference in the AMD between II meiotic triploids and diploids, and between I meiotic

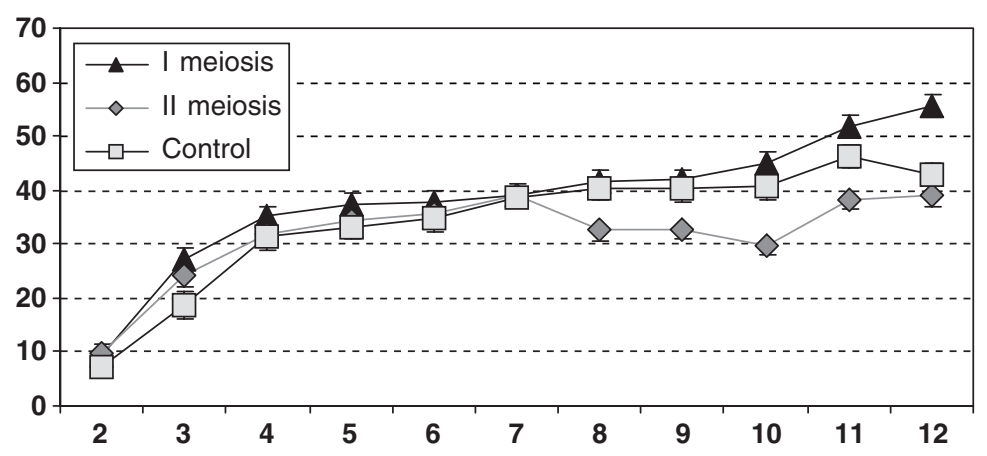

Figure 1 Shell height $(\mathrm{mm})$ of diploid and triploid oyster Crassostrea madrasensis (mean $\pm \mathrm{SE}$ ). 

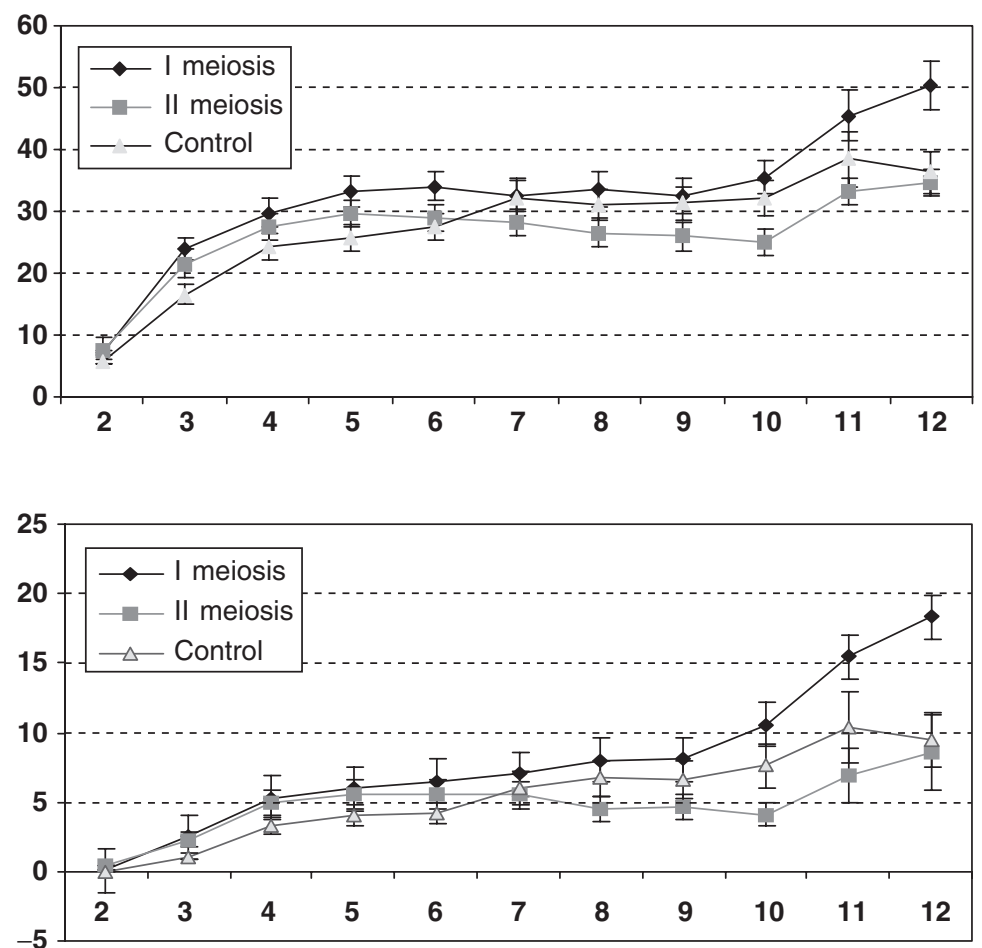

Figure 2 Breadth (mm) of diploid and triploid oyster Crassostrea madrasensis (mean $\pm \mathrm{SE}$ ).

Figure 3 Weight $(\mathrm{mm})$ of diploid and triploid oyster Crassostrea madrasensis (mean $\pm \mathrm{SE}$ ).

triploid and diploid oysters, was found to be significant $(P<0.05)$ (Table 4).

\section{Dry meat weight}

The ANOVA indicated high significance $(P<0.05)$ between the differences in dry meat weight of I and II meiotic triploids with the diploid (Table 4). The II meiotic triploids had $67 \%$ higher dry weight than the diploid, and in the I meiotic triploids the dry meat weight was $126 \%$ more than that of the diploid (Table 5).

\section{Condition index}

Condition index plays an important role in marketing the oyster meat. High index values in triploids were observed in all the months over the diploid siblings (Table 4). The percentage difference of condition index between I meiotic triploids and diploid was higher $(177.2 \%)$ than that between II meiotic triploids and diploid $(75.9 \%)$ (Table 5). The ANOva between the differences of condition index of I meiotic triploids and diploids $(P<0.05)$ and II meiotic triploids and diploids $(P<0.05)$ indicated a significant difference.

\section{Discussion}

We attribute initial mortality to the combined effect of strip spawning, egg quality and treatment with 6DMAP. Our results showing that I meiotic C. madrasensis grew significantly faster than diploid controls corresponds to a number of other reports for other bivalves such as Mytilus edulis Beaumont and Kelly (1989); Ostrea edulis Hawkins, Day, Gerard, Naciri, Ledu, Bayne and Heral (1994); Tapes philippinarum Utting et al. (1996) and S. commercialis Nell et al. (1994). This might be explained by the reduced energetic spending for gametogenesis, energy being preferentially used for growth (Allen \& Downing 1986).

The growth rate in the length of I meiotic triploid was $3.87 \mathrm{~mm} / \mathrm{month}^{-1}$, which is greater than that of the diploid $(2.99 \mathrm{~mm})$ and II meiotic $(2.45 \mathrm{~mm})$ oysters. Triploid oysters created during the release of the I polar body are characterized by higher heterozygosity and would yield enhanced growth (Stanley, Hidu \& Allen Jr 1984; Yamamoto, Sugawara, Nomura \& Oshino 1988).

The growth observed in this experimental study is much lesser than the 80-90 mm in length and 80$100 \mathrm{~g}$ in weight obtained by Nayar (1987). This may be because of differential brood and seeds produced from stripping. Our results show that greater size het- 
Table 4 Growth parameters of oyster at different months of growth

\begin{tabular}{lccrr}
\hline & January 2002 & April 2002 & July 2002 & October 2002 \\
\hline $\begin{array}{l}\text { Adductor Muscle Diameter (mm) } \\
\text { I Meiosis }\end{array}$ & & & \\
II Meiosis & $4.1 \pm 0.38$ & $6.5 \pm 0.54$ & $8.3 \pm 0.56$ & $15.5 \pm 1.07$ \\
$\quad$ Diploid & $4.0 \pm 0.64$ & $5.8 \pm 0.42$ & $6.6 \pm 1.06$ & $9.8 \pm 2.54$ \\
Dry weight (g) & $2.9 \pm 0.49$ & $4.2 \pm 0.49$ & $4.3 \pm 0.37$ & $5.6 \pm 0.92$ \\
I Meiosis & & & \\
II Meiosis & $0.07 \pm 0.03$ & $0.12 \pm 0.02$ & $0.52 \pm 0.05$ & $1.45 \pm 0.03$ \\
$\quad$ Diploid & $0.03 \pm 0.02$ & $0.10 \pm 0.05$ & $0.23 \pm 0.03$ & $0.86 \pm 0.07$ \\
Condition Index & $0.02 \pm 0.02$ & $0.04 \pm 0.01$ & $0.10 \pm 0.05$ & $0.19 \pm 0.02$ \\
I Meiosis & & & & \\
II Meiosis & $69.2 \pm 1.8$ & $71.6 \pm 1.21$ & $121.2 \pm 2.21$ & $133.5 \pm 1.67$ \\
$\quad$ Diploid & $63.8 \pm 6.11$ & $66.9 \pm 1.38$ & $55.3 \pm 1.74$ & $108.5 \pm 3.29$ \\
\hline
\end{tabular}

All values are expressed as mean \pm SE $P<0.05$.

Table 5 Differentials percentage of various parameters between triploids and diploid Crassostrea madrasensis

\begin{tabular}{lccc}
\hline & \multicolumn{2}{l}{ Difference \% } & \\
\cline { 2 - 4 } & I \& Control & || \& Control & I \& II \\
\hline Length (mm) & 87.31 & 53.44 & 22.09 \\
Breadth (mm) & 60.06 & 39.64 & 14.61 \\
Width (mm) & 99.19 & 49.98 & 32.76 \\
Total Weight $(\mathrm{g})$ & 260.05 & 128.17 & 57.77 \\
Dry weight & 126 & 67 & 68.60 \\
Condition index & 177.17 & 75.916 & 23.05 \\
AMD (mm) & 50.50 & 22.30 & 57.62 \\
\hline
\end{tabular}

AMD, Adductor muscle diameter.

erogeneity is a triploid characteristic. Similar observations of a high index of AMD have been reported for the triploid C. gigas (Yamamoto et al. 1988). The high AMD may be because of storage of glycogen in the adductor muscle of triploids as the same is not used for gonadal maturation, as attributed by Barber and Blake (1991). Tabarini (1984) also observed that the glycogen concentration in the adductor muscle of triploid Argopecten irradians was as high as 135\% than that in the adductor muscle of diploid scallop. According to Goulletquer, Joly, Gerard, Le Gagneur, Moriceau, Peignon, Heurtebise and Phelipot (1996), the reason for metabolic changes of triploids like size difference, abnormal reproductivity, etc. was the abnormal functioning neurosecretory systems affected by treatment. The $126 \%$ of dry meat weight increase in triploids is expected to attract oyster farmers and this will lead to increased production of oyster meat by farming triploid C. madrasensis. Muthiah, Rajapandian, Ramdoss, Appukuttan and Velayudhan
(2000) estimated production of diploid oyster as 80 tha $^{-1}$ using the rack and string method but, in triploid oysters, the yield can even be increased to $100 \mathrm{tha}^{-1}$. As the growth rate of triploid C. madrasensis $\left(12.9 \mathrm{~m} \mathrm{day}^{-1}\right)$ is more than that of diploids, the farming duration will be reduced to 7 months, compared with 12 months for diploids. This will facilitate better farm management and reduction in the cost of the production of oysters.

The faster growth of triploids over diploids has been attributed to the more heterozygous individuals having higher probability of carrying two or three different alleles in the same locus as indicated in allelic variation hypothesis (Stanley et al. 1984; Yamamoto et al. 1988; Beaumont \& Kelly 1989). Zouros, Thiriotquievreux and Kotoulas (1996) were of the view that faster growth in triploids occurs because of the probability of exposing deleterious alleles in a much smaller level. Guo and Allen (1994) opined that nongenetic factors such as energy reallocation from gonad to somatic tissues might be responsible for faster triploidy growth. The gene dose hypothesis indicates that faster growth in polyploidy is due to gene products in triple dose. Under the gene dose hypothesis, I meiotic and II meiotic triploids should not differ in their growth rate. In the present study, the higher growth of I meiotic over II meiotic triploids may be due to increased heterozygosity of I meiotic triploids as observed in Crassostrea virginica (Stanley et al. 1981), C. gigas (Yamamoto et al. 1988; Hawkins, Magoulas, Heral, Bougrier, Naciri-graven, Day \& Kotoulas 2000).

In this, triploid oyster grew better than their diploid sibling, especially I meiotic triploids. A condition index of 80 or above is preferred for marketing 
edible oyster. It was reached earlier by triploids rather than diploids. First meiotic triploids maintained its high condition indices from the ninth month of growth onwards. High difference percentage between I meiotic triploids and control than II meiotic triploid and control was a factor to note as I meiotic triploids show greater growth than II meiotic triploids.

\section{Acknowledgments}

We thank Dr Mohan Joseph Modayil, the director of CMFRI for providing facilities for this work. We also thank ICAR for financial support with Agricultural Productive Cess fund for this study. We are grateful to Mr J. X. Rodrigo (Technical officer; Tuticorin Research Centre of CMFRI) for providing micro-algae during larval rearing.

\section{References}

Akashige S. (1990) Growth and reproduction of triploid Japanese oyster in Hiroshima Bay. In: Advances in Invertebrate Reproduction 5. Proceeding of 5th International Congress Invertebrate Reproduction (ed. by M. Hoshi \& O. Yamashita), Nagoya. 1989). pp. 461-468. Elsevier, Amsterdam, the Netherlands.

Allen S.K. Jr. \& Downing S.L. (1986) Performance of triploid Pacific Oysters, Crassostrea gigas (Thunberg). I. Survival, growth, glycogen content and sexual maturation in yearlings. Journal of Experimental Marine Biology and Ecology 102, 197-208.

Appukuttan K.K. \& Muthiah P. (1996) Technology of edible oyster culture. Bulletin of Central Marine Fisheries Research Institute 48, 64-69.

Barber B.J. \& Blake N.J. (1991) Reproductive physiology. In: Scallops: Biology Ecology and Aquaculture (ed. by S.E. Shumway), pp. 377-428. Elsevier, Amsterdam, the Netherlands.

Beaumont A.R. \& Kelly K.S. (1989) Production and growth of triploid Mytilus edulis larvae. Journal of Experimental Marine Biology and Ecology 132, 69-84.

Crosby M.P. \& Gale L.D. (1990) A review and evaluation of bivalve condition index methodologies with a suggested standard method. Journal of Shellfish Research $\mathbf{9}$, 233-237.

Gardner C., Maguire G.B. \& Kent G.N. (1996) Studies on triploid oysters in Australia.VII. Assessment of two methods for determining triploidy in oysters: adductor muscle diameter and nuclear size. Journal of Shellfish Research 15, 609-615.

Gopinathan C.P. (1982) Methods of culturing phytoplankton. In: Manual of Research Methods for Fish and Shellfish
Nutrition. CMFRI special Publication, Central Marine Fisheries Research Institute, Cochin. 8, pp. 113-118.

Goulletquer P., Joly J.P., Gerard A., Le Gagneur E., Moriceau J., Peignon J.M., Heurtebise S. \& Phelipot P. (1996) Performance of triploid Pacific oysters Crassostrea gigas (Thunberg) reared in high carrying capacity ecosystem: survival, growth and proximate biochemical composition. Haliotis 25, 1-12.

Graham M. (1991) A situation analysis of the Australian oyster industry with particular reference to the Tasmanian Pacific oyster. A report prepared for the Tasmanian Aquaculture, Co-operative Society and The Business School, University of Tasmania, Hobart,Tas., Australia, 81pp.

Guo X. \& Allen S.K. Jr. (1994) Reproductive potential and genetics of triploid Pacific oysters Crassostrea gigas (Thunberg). Biological Bulletin 187, 309-318.

Hand R.E., Nell J.A. \& Maguire G.B. (1998) Studies on triploid oysters in Australia, X. Growth and mortality of diploid and triploid Sydney rock oysters Saccostrea commercialis (Iredale and Roughley). Journal of Shellfish Research 17, 1115-1127.

Hawkins A.J.S., Day A.J., Gerard A., Naciri Y., Ledu C., Bayne B.L. \& Heral M. (1994) A genetic and metabolic basis for faster growth among triploids induced by blocking meiosis I but not meiosis II in the larviparous European flat oyster, Ostrea edulis L. Journal of Experimental Marine Biology and Ecology 184, 21-40.

Hawkins A.J.S., Magoulas A., Heral M., Bougrier S., NaciriGraven Y., Day A.J. \& Kotoulas G. (2000) Separate effects of triploidy, parentage and genomic diversity upon feeding behaviour, metabolic efficiency and net energy balance in the Pacific oyster Crassostrea gigas. Genetical Research 76, 273-284.

Komaru A. \& Wada K.T. (1989) Gametogenesis and growth between diploid and triploid scallops Chlamys mobillis. Nippon suisan Gakkaishi 55, 447-452.

Mason K.M., Shumway S.E., Allen S.K. Jr. \& Hidu H. (1988) Induced triploidy in the soft-shelled clam Mya arenaria: energetic implications. Marine Biology 98, 519-528.

Matthiessen G.C. \& Davis J.P. (1992) Observations on growth rate and resistance to MSX (Haplosporidium nelsoni) among diploid and triploid eastern oysters, (Crassostrea virginica (Gmelin, 1791)) in New England. Journal of Shellfish Research 11, 449-454.

Muthiah P., Rajapandian M.E., Ramdoss K., Appukuttan K.K. \& Velayudhan T.S. (2000) The edible oyster culture. In: Marine Fisheries Research and Management (ed. by V.N. Pillai \& N.G. Menon), pp. 786-801. Central Marine Fisheries Research Institute, Cochin, India.

Nayar K.N. (1987) Technology of Oyster farming. In: Oyster culture - Status and Prospects. K.N. Nayar \& S. Mahadevan (eds,). Bulletin of Central Marine Fisheries Research Institute, Central Marine Fisheries Institute, Cochin, 38 59-62.

Nayar K.N., Rao S.K., Rajapandian M.E. \& Gopinathan C.P. (1987) Production of oyster seed in a hatchery system. In: 
Oyster Culture - Status and Prospects (ed. by K.N. Nayar \& S. Mahadevan). Bulletin of Central Marine Fisheries Research Institute 38, pp. 52-58.

Nell J.A., Cox E., Smith I.R. \& Maguire G.B. (1994) Studies on triploid oyster in Australia: I The farming potential of triploid Sydney rock oysters, Saccostrea commerciallis (Iredale \& Roughley). Aquaculture 126, 243-255.

Ruiz-Verdugo C.A., Ramrez J.L., Allen S.K. Jr. \& Ibarra A.M. (2000) Triploid catarina scallop (Argopecten ventricosus, Sowerby II, 1842): growth, gametogenesis, and suppression of functional hermaphroditism. Aquaculture 186, $13-32$.

Stanley J.G., Allen S.K. Jr. \& Hidu H. (1981) Polyploidy induced in the American oyster, Crassostrea virginica, with cytochalasin B. Aquaculture 23, 1-10.

Stanley J.G., Hidu H. \& Allen S.K. Jr. (1984) Growth of American Oysters increased by Polyploidy induced by blocking Meiosis I but not Meiosis II. Aquaculture 37, 147-155.
Tabarini C.L. (1984) Induced triploidy in the bay scallop, Argopecten irradians and its effect on growth and gametogenesis. Aquaculture 42, 151-160.

Utting S.D., Millican P.F. \& Laing I. (1996) The breeding potential and biochemical composition of triploid Manila clams Tapes philippinarum Adams \& Reeve. Aquaculture Research 27, 573-580.

Yamamoto S., Sugawara Y., Nomura T. \& Oshino A. (1988) Induced triploidy in Pacific oyster Crassostrea gigas, and performance of triploid larvae. Tohoku Journal of Agricultural Research 39, 47-59.

Zouros E.,Thiriot-Quievreux C. \& Kotoulas G. (1996) The negative correlation between somatic aneuploidy and growth in the oyster Crassostrea gigas and implications for the effects of induced polyploidization. Genetical Research 68, 109-116. 